\title{
REFLEXÕES SOBRE A NECESSIDADE DE HARMONIZAÇÃO LEGISLATIVA NO \\ MERCOSUL
}

JOSÉ SÉRGIO SARAIVA MARCELO TOFFANO

ISSUE DOI: $10.21207 / 1983.4225 .594$

\section{RESUMO}

No âmbido jurídico é extremamente importante identificar as dificuldades encontradas para harmonizar o proceso legislativo da área de livre comércio do Mercosul, diante da ausência até então de uniformização legislativa comum as partes envolvidas, dificultando o julgamento por parte dos Poderes Judiciários envolvidos ou mesmo as Cortes Supremas do bloco. Reuniões aconteceram, inclusive no ano de 2006, em Brasília-DF, com participação de países associados, representantes europeus, estudiosos, empesários, em suma, todos os interessados e envolvidos, justamente com objetivo e fomentar leis comuns, conferir maior segurança jurídica e harmonização legislativa ao bloco. Acreditando que a origem comum e afinidades entre os signatários facilitaria a homonização legislativa, o que não ocorreu, conforme será demonstrado. Pensou-se em um Direito próprio, material e processual, com força política de inserção na ordem interna dos países-membros, afastando o direito estrangeiro ou inernacional. Pensou-se em um Direito no Mercosul fundamental para proteção dos direitos econômicos. Por fim, chegou-se a cogitar de criação de normas mínimas de ga- 
rantia de direitos trabalhistas e direitos humanos e o papel do juiz na solução de conflitos advindos do Mercosul. As leis de cada signatário, as experiências sociais e a cultura e cada País, são marcas que dificulta uma harmonização a legislação. Senão bastasse as características distintas, também a diferença de estrutura orgânica entre os mercados comuns, europeu e aquele referente ao Mercosul, foram destacadas. Têm-se um Protocolo Adicional do Tratado de Assunção sobre a Estrutura Institucional do Mercosul denomiando "Protocolo de Ouro Preto", visando manter um mínimo de estrutura administrativa e jurídica. Não há órgão de caráter supranacional, mas há compromisso dos signatários de harmonizar a legislação nos moldes do modelo supranacional da União Européia.

Palavras-chave: Constituição Federal. Processo Legislativo. Mercosul. Direito da Integração. Direito no Mercosul.

\section{INTRODUÇÃO}

Entre as dificuldades encontradas no processo de harmonização legislativa da área de livre comércio do Mercosul estão as diferenças entre as sociedades que compõem o bloco.

Os poderes judiciários do bloco já se reuniram três vezes com o propósito de debater o tema.

No ano de 2006, a terceira edição do encontro, realizada em Brasília, contou com a participação dos presidentes das cortes supremas do Mercosul e países associados, representantes europeus, autoridades, estudiosos, empresários e jornalistas. A idéia dos encontros é fomentar leis comuns e conferir maior segurança jurídica e harmonização legislativa ao bloco.

A princípio, pensava-se que esta harmonização não encontraria grandes obstáculos, pois o sistema jurídico dos países signatários tem muitas afinidades entre si, devido a sua origem comum, mas com o passar do tempo, constatou-se que este processo não seria tão simples.

A problemática referente a esse assunto opera-se quando se indaga como se dará a referida harmonização das legislações, quais suas finalidades. 
Para facilitar a harmonização legislativa entre os países integrantes do Mercosul, a representante da Corte Suprema da Argentina, ministra Elena Highton de Nolasco, sugeriu em 30/11/2004 a criação de um Direito próprio, com força política de inserção na ordem interna dos países-membros. A ministra participa do $2^{\circ}$ Encontro de Cortes Supremas do Mercosul que discutiu, a harmonização legislativa em direito material e processual.

Elena Highton acredita que o "direito comum" entre os países do Cone Sul deve ter aplicação imediata e supremacia sobre direitos nacionais, pois não se trata, segundo ela, de direito estrangeiro ou internacional. É "principalmente direito de integração", afirmou. Para a ministra, o sistema intergovernamental hoje existente no Mercosul, sem poder imperativo e autonomia, é um empecilho à harmonização.

A representante da Corte Suprema argentina sustentou, ainda, que a harmonização do direito no Mercosul é fundamental para a proteção dos direitos econômicos daqueles que poderiam ser prejudicados pela internacionalidade dos mercados. Ela apontou que 50\% das normas dos órgãos do Mercosul não foram incorporadas aos ordenamentos jurídicos dos países integrantes. "O que preocupa, se levarmos em consideração que se tratam de normas aprovadas por consenso pelos representantes dos quatro países e se relacionam diretamente com o tema da harmonização", assinalou.

Por fim, a ministra argentina ressaltou a criação de normas mínimas de garantia de direitos trabalhistas e direitos humanos e o papel do juiz na solução de conflitos advindos do Mercosul. "Todo juiz nacional deverá fazer um estudo do 'direito do Mercosul' e imprimir uma interpretação dinâmica e teleológica do direito em cada caso concreto", finaliza.

De acordo com ministro Eros Grau, do Supremo Tribunal Federal do Brasil, a produção de normas envolve a consideração da lei, dos fatos e das experiências sociais de cada país.

"Eu temo que mesmo que se imponha ao povo do Mercosul os mesmos textos, que ainda assim as normas produzidas a partir destes textos sejam distintas, porque são distintas as nossas realidades", disse o ministro. 
Na declaração final do encontro de 2005, os participantes se comprometeram a contribuir com o processo de integração do Mercosul apontando, inclusive, a Imprensa como grande aliada.

Para Roberto Ruiz Diaz Labramo, do Centro Mercosul do Estado de Direito, a solução às questões da integração, debatidas no encontro, "contribuem para que se encontre uma fórmula final para todos os estados conseguirem uma maior seguridade política, maior celeridade política e maior certeza política, o que ajudaria na segurança jurídica do bloco".

Antes de adentrarmos propriamente na matéria relativa à harmonização da legislação societária no Mercosul, torna-se oportuna uma rápida abordagem no que concerne à diferença de estrutura orgânica observada entre os mercados comuns (europeu e aquele referente ao Mercosul).

Considerando-se a sua judiciosa exposição acerca da matéria, não será demais repetir as palavras de Werter R. Faria nesta passagem:

"O Tratado de Assunção difere profundamente do Tratado CEE na parte relativa à estrutura orgânica dos dois mercados comuns. No europeu, a realização das tarefas confiadas à Comunidade compete a cinco órgãos: o Parlamento Europeu, o Conselho, a Comissão, o Tribunal de Justiça e o Tribunal de Contas. Com exceção do Conselho, composto por representantes dos Estados-Membros, designados pelos respectivos governos, as demais instituições são integradas por membros eleitos (Parlamento), escolhidos pelos Estados-Membros em razão da sua competência e que ofereçam todas as garantias de independência (Comissão) ou, além destas garantias, reunam as condições exigidas, nos respectivos países, para o exercício das mais altas funções jurisdicionais ou que sejam jurisconsultos de reconhecida competência, nomeados, de comum acordo, pelos governos dos Estados-Membros (Tribunal de Justiça), escolhidos pelo Conselho dentre personalidades que pertençam ou tenham pertencido, nos respectivos países, a instituições de fiscalização externa ou que possuam uma aptidão especial para essa função (Tribunal de Contas). Quatro das cinco instituições são supranacionais. A exceção é o Conselho.

O Protocolo Adicional do Tratado de Assunção sobre a Estrutura Institucional do Mercosul - Protocolo de Ouro Preto -, embora o tenha personificado, manteve os órgãos existentes durante o período de transição: o Conselho do Mercado Comum, o Grupo Mercado Comum e a Comissão Parlamentar Conjunta e criou a Comissão de Comércio do Mercosul, o Foro Consultivo Econômico-Social e a Secretaria Administrativa do Mercosul. 
Nenhum dos seis órgãos tem caráter supranacional. A própria Comissão Parlamentar Conjunta é um órgão representativo dos Parlamentos nacionais no seio do Mercosul. $\mathrm{O}$ artigo 23 do Protocolo deixa expresso que os integrantes da Comissão são 'parlamentares representantes dos Estados-Partes', e não representantes de seus povos. Em virtude do caráter intergovernamental dos órgãos do Mercosul dotados de capacidade decisória, a harmonização das legislações fica restrita a decisões do Conselho do Mercado Comum e a convenções entre os Estados-Partes."

Como consectário do que foi afirmado supra, temos que as decisões do Conselho do Mercosul não produzem efeitos diretos sobre os ordenamentos jurídicos dos Estados-Partes, apenas vincula-os no sentido de introduzirem as normas de harmonização em seus respectivos ordenamentos jurídicos, através da hierarquia de lei, se esta for reguladora da matéria, ou, ainda, se competir ao Parlamento nacional a delimitação da matéria.

Temos como condição para se alcançar o Mercado Comum, a unificação de certos regramentos jurídicos, de forma a possibilitar iguais condições de competição entre os países integrados. ${ }^{1}$

$\mathrm{O}$ art. $1^{\circ}$ do Tratado de Assunção dispõe sobre o compromisso, dos Países - membros, de harmonizar suas legislações, nas áreas pertinentes, para lograr o fortalecimento do processo de integração. ${ }^{2}$ Assim, os Países - membros devem adaptar sua legislação com base nas necessidades da integração. As áreas pertinentes são aquelas que não foram tratadas pelo Mercosul, e cuja desarmonia poderá afetar a consecução dos objetivos propugnados. $^{3}$

Existe distinção entre coordenação, harmonização e aproximação. Segundo a doutrina mais autorizada, coordenadas seriam as normas jurídicas que não apresentam incompatibilidades, harmonizadas as que produzem os mesmos efeitos e aproximadas as que adotam diretivas de órgãos comunitários supranacionais. ${ }^{4}$

\footnotetext{
${ }^{1}$ MERCOSUL.Tratado de Assunção. Disponível em: <http://www.mercosul.gov.br/textos/default.asp?key=45>. Acesso em: 29 jul. 2009.

${ }^{2}$ BÖHLKE, Marcelo. Integração regional e autonomia do seu ordenamento jurídico. Curitiba: Juruá, 2002. p. 219.

${ }^{3}$ ARAÚJO, Clarice. Aspectos tributários para a integração dos países signatários do Mercosul. Direito da integração/Coordenadora Rachel Sztajn - São Paulo: Cultural Paulista: Unicid, 2001.

${ }^{4}$ COELHO, Fábio Ulhoa. Curso de direito comercial. $7^{\mathrm{a}}$ ed. São Paulo: Saraiva, 2003. Vol. 1. p. 102.
} 
Segundo Werter R. Faria a "harmonização tem por objeto suprimir ou atenuar as disparidades entre as disposições de direito interno, na medida em que o exija o funcionamento do Mercado Comum. Assim, a harmonização importa a alteração dos respectivos conteúdos".

A finalidade da harmonização legislativa, para Ricardo Soares Stersi dos Santos, é o estabelecimento de um conjunto de regras harmônicas, entre os estados - partes, fundamentadas no Direito da Integração. O Direito da Integração é o ordenamento jurídico instituído para orientar o processo de integração. ${ }^{6}$

A harmonização das legislações, segundo Werter R. Faria ${ }^{7}$, opera-se quer pela adoção de novas normas jurídica, quer pela eliminação ou redução das diferentes entre as existentes que prejudiquem a constituição e funcionamento do Mercado Comum.

Conforme asseveram Frederico Thales de Araújo Martos e José Antonio de Faria Martos:

\begin{abstract}
Al principio se pensaba que esta armonización no encon-traría grandes obstáculos pues el sistema jurídico de los países sig-natarios cuenta con muchas afinidades entre sí, debido a su origen en común, pero con el pasar del tiempo se constató que este pro-ceso no sería tan simple.

La problemática referente a este asunto opera cuando se indaga cómo se daría la referida armonización de legislaciones y cuáles sus finalidades. ${ }^{8}$
\end{abstract}

\footnotetext{
${ }^{5}$ FARIA, Werter R. Métodos da harmonização aplicáveis no Mercosul e incorporação das normas correspondentes nas ordens jurídicas internas. In: Mercosul: seus efeitos jurídicos, econômicos e políticos nos Estados-partes, org. maristela Basso. - 2. Ed. - Porto Alegra: Livraria do Advogado, 1997.

${ }^{6}$ SANTOS, Ricardo Soares Stersi dos. Mercosul e arbitragem internacional comercial: aspectos gerais e algumas possibilidades. Belo Horizonte: Del Rey, 1997

${ }^{7}$ FARIA, Werter R. Métodos da harmonização aplicáveis no Mercosul e incorporação das normas correspondentes nas ordens jurídicas internas. In: Mercosul: seus efeitos jurídicos, econômicos e políticos nos Estados-partes, org. maristela Basso. - 2. Ed. - Porto Alegra: Livraria do Advogado, 1997.

${ }^{8}$ MARTOS, Frederico Thales de Araujo, MARTOS José Antonio de Faria, Las interceptaciones telefónicas en los países del Mercosur: doctrina y Jurisprudencia en el proceso civil. Franca: Editora Lemos \& Cruz, 2015, p. 230
} 
A harmonização não elimina todas as diferenças entre as legislações, mas apenas aquelas prejudiciais à integração. ${ }^{9}$

A harmonização de legislações é um requisito fundamental para que a livre circulação de bens, pessoas e fatores produtivos se cumpra sem restrições. ${ }^{10}$

Quanto à aplicação interna das normas, no art. 38 do Protocolo de Ouro Preto, os Estados - Partes obrigaram-se a adotar todas as medidas necessárias para assegurar o cumprimento das normas emanadas dos órgãos do Mercosul, com capacidade decisória, dentro de seus territórios. ${ }^{11}$

O órgão responsável pela harmonização legislativa, entre as legislações nacionais doa países integrantes do Mercosul é o Conselho Mercado Comum. ${ }^{12}$

Como já se salientou, devido ao modelo de intergovernamentabilidade adotado, as normas emanadas dos órgãos do Mercosul não possuem aplicabilidade direta, precisam ser incorporadas ao ordenamento jurídico interno de cada um dos países signatários, conforme suas disposições constitucionais. As normas precisam ser incorporadas para que estabeleçam direitos e obrigações plenas no ordenamento jurídico interno dos Estados partes. ${ }^{13}$

Do exposto, não é necessária uma grande reflexão para atentar ao fato de que o sistema de intergovernamentabilidade adotado é uma barreira para se alcançar a integração pretendida. A cada dia torna-se mais gritante a necessidade da adoção, pelo Mercosul, de órgãos com capacidade decisória vinculante, para se obter uma harmonização legislativa ágil e completa.

\footnotetext{
${ }^{9}$ BÖHLKE, Marcelo. Integração regional e autonomia do seu ordenamento jurídico. Curitiba: Juruá, 2002

${ }^{10}$ LIPOVETZKY, Jaime César e LOPOVETZKY, Daniel Andrés. Mercosul, estratégia para a integração. São Paulo: LTr, 1994.

11 MERCOSUL. Protocolo de Ouro Preto. Disponível em: <http://www.mercosul.gov.br/textos/default.asp?Key=17>. Acesso em: 29 jul. 2009.

${ }^{12}$ ARAÚJO, Clarice. Aspectos tributários para a integração dos países signatários do Mercosul. Direito da integração/Coordenadora Rachel Sztajn - São Paulo: Cultural Paulista: Inicid, 2001

${ }^{13}$ BÖHLKE, Marcelo. Integração regional e autonomia do seu ordenamento jurídico. Curitiba: juruá, 2002.
} 
O modelo supranacional adotado pela União Européia é exemplo, a ser seguido, de agilidade e sucesso, tanto no tocante à harmonização das legislações, quanto no desenvolvimento do processo de integração.

\section{HARMONIZAÇÃO LEGISLATIVA DOS ESTADOS- PARTES DO MERCOSUL}

O artigo 38 do Protocolo de Ouro Preto, o qual institucionalizou o MERCOSUL, dando prosseguimento ao período de transição iniciado com o Tratado de Assunção, reza que os Estados-partes comprometem-se a adotar todas as medidas necessárias para assegurar, em seus respectivos territórios, o cumprimento das normas emanadas dos órgãos do MERCO$S U L$, porém, vezes há em que faz-se mister uma aproximação das legislações ou uma harmonização das mesmas. Esta tem por objetivo suprimir ou amenizar as diferenças entre as disposições de direito interno, na medida em que o exija o funcionamento do Mercado Comum, importa a alteração dos respectivos conteúdos. Já a aproximação das legislações correlacionase com o procedimento especial para garantir o bom funcionamento do Mercado Comum. Apesar de constituírem-se procedimentos diferentes, ambos pretendem estabelecer uma certa conformidade entre as disposições legislativas que já vigoram ou irão vigorar nos Estados empenhados num processo de integração.

Desta maneira, é impossível discutir-se uma integração do MERCOSUL ignorando a harmonização das leis de âmbito internacional com as leis internas. A integração regional, traz benefícios e, inerentemente, certos ônus, que são compartilhados.

É de suma importância ressaltar que a consecução dos objetivos do MERCOSUL depende essencialmente que suas deliberações sejam efetivamente acatadas pelos Estados-partes e, para tanto, é indispensável existir um rápido e eficaz processo de harmonização legislativa do direito internacional para o interno, o que na prática não vem ocorrendo em virtude das divergências constitucionais dos países membros.

Essas divergências trazem, para os Estados-partes, grandes incertezas em relação ao futuro no que concerne às questões jurídico-institucionais. A falta da supranacionalidade gera insegurança jurídica e instabilidade devido a uma não interpretação e aplicação uniforme das normas e provoca a falta de confiabilidade externa em decorrência do risco efetivo 
ao princípio basilar do direito internacional, o pacta sunt servanda. Além do mais, por serem os tratados submetidos, em todos os Estados-partes, ao princípio lex posterior derogat priori, uma alteração legislativa poderia provocar o descumprimento crônico dos compromissos ora assumidos.

Ao dissertar sobre os princípios afirma Frederico Thales de Araújo Martos que além da função de melhorar a interpretação das normas e complementar as lacunas legais, eles também possuem função normativa própria. Assim sendo, gozam de total efetividade jurídica. ${ }^{14}$

Por fim, cabe ilustrar como se apresentam essas divergências constitucionais entre os ordenamentos jurídicos internos dos Estados-partes do MERCOSUL: no Uruguai, a Constituição nada assinala quanto à hierarquia dos tratados internacionais 10, deixando as soluções dos conflitos a cargo da jurisprudência nacional. No Paraguai, os tratados, convênios e todas as espécies de acordos aprovados e ratificados possuem hierarquia superior às leis sendo, destarte, inferiores à própria Carta Magna. Na Argentina, tem-se a prevalência dos tratados sobre o direito interno infraconstitucional. E, por fim, no Brasil, segundo o Supremo Tribunal Federal $^{11}$, os tratados internacionais equiparam-se à lei federal e, portanto, podem sofrer controle da constitucionalidade.

Em vista dos aspectos supracitados fica evidente a incompatibilidade dos ordenamentos jurídicos internos dos Estados-partes, o que, sem dúvida alguma, apresenta-se como um empecilho a uma real integração político-econômica do bloco.

\section{OS MÉTODOS DE HARMONIZAÇÃO DO MERCOSUL}

Reza a quarta parte do Tratado de Assunção que este mercado comum implica no "compromisso dos Estados Partes de harmonizar suas legislações, nas áreas pertinentes, para lograr o fortalecimento do processo de integração". Primeiramente vamos comparar a linguagem vaga deste tratado, com o que constituiu a CEE em 1957, citado no começo do capítulo das Diretivas. No primeiro caso fala-se em "compromisso dos Estados Partes" e em "áreas pertinentes para lograr o fortalecimento do processo de integração", no segundo em uma "ação da comunidade" e se afirma que "o

\footnotetext{
${ }^{14}$ MARTOS, Frederico Thales de Araújo. Direito Empresarial Moderno: A função social da empresa contemporânea. Franca: Editora Lemos e Cruz, 2015, p.96.
} 
Conselho deliberando por unanimidade, sob proposta da Comissão, adotará as Diretivas". Com muita nitidez vemos a diferença entre entre a "harmonização supranacional" e a nossa tradicional "harmonização internacional", única atualmente possível no Mercosul (supranacionalidade X soberania). ${ }^{15}$

Ivo E. Schwartz (6), quando membro da Comissão da Comunidade Européia disse que acerca dos métodos de harmonização que, "a escolha do instrumento depende, em primeiro lugar, do objetivo a alcançar. Tratando-se de situações de fato que não podem ser reguladas, de modo satisfatório, senão ultrapassando o caráter limitado do campo de aplicação territorial das leis nacionais, é necessário recorrer a uma convenção". Por outro lado, a Diretiva "é um instrumento apropriado para a aproximação das legislações; entra em jogo quando as soluções encontradas para as regras dos conflitos de leis, as soluções interjurídicas, as leis uniformes ou as soluções de direito comunitário não são suficientes ou necessárias,... A aproximação dos direitos materiais nacionais, no sentido de sua harmonização funcional, este é o domínio próprio da Diretiva. (...) O que importa não é a concordância na letra, no sistema, na técnica jurídica ou na forma, mas o próprio efeito funcional das normas aproximadas." Esta breve explanação mostra-nos a importância de instrumentos mais sólidos que os acordos para a formação de um bloco econômico forte, bem como a função destes em uma integração. Mas, o que tais métodos podem fazer em prol do Mercosul?

Os dois primeiros métodos analisados; quais sejam, as Diretivas e os regulamentos, infelizmente, não são aplicáveis no Mercosul. As normas inseridas por estes métodos não surgem do Direito Internacional, mas de uma organização com ordenamento jurídico próprio, bem como de processos autônomos de produção do direito. Mesmo que o Conselho do Mercosul adotasse normas para a harmonização legislativa dos Estados esta não proviriam de uma fonte autônoma, estariam sujeitas a incorporação nos ordenamentos jurídicos nacionais como determina cada Constituição, esta pode ainda chocar-se com normas de direito interno e como em alguns casos que analisaremos no próximo capítulo ficar abaixo das suas normas ordinárias. Este caráter é ainda confirmado nos artigos 38 e 42 do Protocolo de Ouro Preto (7)

\footnotetext{
${ }^{15}$ KRAMMES, Alexandre G. Harmonização legislativa no Mercosul. Jus Navigandi, Teresina, ano 3, n. 33, jul. 1999. Disponível em: <http://jus2.uol.com.br/doutrina/texto.asp?id=1625>. Acesso em: 19 maio 2008.
} 
Vê-se que as normas emanadas pelo Mercosul ficam longe das da comunidade européia, essas últimas têm valor de lei para os países, o Brasil bem como nossos vizinhos não quisera transferir nenhuma parcela de suas competências legislativas para um ou mais órgãos do mercado comum em formação. É esta ausência de qualquer grau de supranacionalidade que impede uma real harmonização.

Mediante acordo internacional temos dois métodos de harmonização o da lei uniforme, em que as partes se obrigam a introduzir em seus ordenamentos a lei uniforme que é um anexo da convenção; e o da convenção integrada em que a lei uniforme está no seu próprio texto pois já existe a obrigação da harmonização, esta pode ser realizada por acordos entre os Estados ou por decisões dos Conselho. Mais uma vez nenhum destes métodos é aplicável no Mercosul. Pelo que preceitua o artigo 42 do Protocolo de Ouro Preto, estas decisões vinculam os Estados a incorporá-las nos seus ordenamentos. A diferença das convenções integradas é que a obrigação de criar normas para a harmonização e introduzi-las nos territórios preexiste à sua elaboração. A desvantagem deste modelo é a necessidade de atos normativos internos ou ordens de execução e em casos de conflito prevalece o direito interno.

Cada vez mais sentiremos falta de uma estrutura institucional com órgãos que bem se caracterizem como uma pessoa jurídica, e de um tribunal de justiça que assegure a interpretação e funcionamento do mercado comum visado pelos Estados. Por fim não basta estabelecer apenas normas uniformes, o que será já um grande trabalho, deve-se, para uma verdadeira unificação do direito, também velar pela uniformidade da sua interpretação para não se criar uma nova divergência em lugar desta visada uniformidade.

"A integração econômica exige a harmonização progressiva das legislações nacionais, o direito harmonizado, uma interpretação uniforme e esta uma jurisdição supranacional."

\section{AS BARREIRAS CONSTITUCIONAIS PARA HARMONIZAÇÃO LEGISLATIVA NO MERCOSUL}

Toda e qualquer integração, para se efetivar de maneira sólida e segura, deve partir de um ponto essencial, por ser este ponto o elo de liga- 
ção com o mundo jurídico exterior, o direito interno. É de suma importância o tratamento que o modelo institucional de cada Estado dispensa em relação aos tratados internacionais assumidos por este, quer na ordem externa (relação com os outros Estados), quer na ordem interna, no contato das normas vindas destes com seus cidadãos e pessoas jurídicas nacionais.

Pela sua condição de soberano, o Estado enquanto sujeito de direito internacional, pode contrair direitos e obrigações ficando vinculados, ao menos formalmente, a garantir sua validade e eficácia. A soberania do Estado no entanto tem seus limites, quer seja no próprio tratado ratificado por este, quer seja pelas normas internacionais gerais, o jus cogens, regulado pela Convenção de Viena e seu artigo 53 enquanto uma norma aceita e reconhecida por todos os Estados. A condição soberana do Estado não pode ser então invocada contra legem.

Ao serem assinados e ratificados o Tratado de Assunção e o Protocolo de Ouro Preto pelos países membros, esses foram inseridos em seus direitos internos (9), "a partir da ratificação e consequente inserção dos tratados nas ordens jurídicas internas, resta assegurar a coerência do ordenamento jurídico e a compatibilidade das obrigações resultantes" dos tratados e protocolos, "com os direitos nacionais, especialmente quanto as normas de natureza constitucional." (10) Deveríamos esperar tal coerência, o problema é que esta nem sempre ocorre, e isto não pode acontecer, a dimensão constitucional é um dado fundamental para a integração.

Esta divergência entre normas constitucionais de um lado e normas do Mercosul de outro deve ser resolvida de qualquer modo, quer seja por uma revisão constitucional, que ao meu ver seria o mais coerente, mediante renegociação das obrigações resultantes do Tratado ou com a denúncia destes caso não sejam eliminadas tais distorções até a adoção de uma estrutura mais coesa, este último, num caso extremo.

Para termos uma cosmovisão das constituições abordarei a partir de agora cada uma isoladamente.

\subsection{A Constituição Argentina}

O Artigo 67 de Carta Magna argentina havia sido modificado na reforma de 1860 e continha em relação ao tema: 
Atribuciones del Congreso

Artículo 67 - Corresponde al Congreso: (...)

19. Aprobar o desechar los tratados concluidos con las demás naciones, y los concordatos con la Silla Apostolica; y arreglar el ejercicio del patronato en toda la Nación

A revisão feita em 1994 na Constituição argentina trouxe boas e interessantes perspectivas em matéria de uma integração supranacional. $\mathrm{O}$ dispositivo citado foi substituído pelo artigo 75, em que se incluíram os seguintes incisos:

Artículo 75 - Corresponde al Congreso: (...)

22. Aprobar o desechar tratados concluídos con las demás naciones y con las organizaciones internacionales y con los concordatos con la Santa Sede. Los tratados y concordatos tienen jerarquía superior a las leyes. (...)".

24. Aprobar tratados de integración que deleguen competencias y jurisdicción a organizaciones supraestatales en condiciones de reciprocidad e igualdad, y que respeten el orden democrático y los derechos humanos. Las normas dictadas en su consecuensia tienen jerarquía superior a las leyes" [sem grifo no original].

A preocupação dos legisladores argentinos é muito clara em possibilitar que a regra comunitária entre no ordenamento nacional; primeiro porque se fala em uma supraestatalidad, claramente se referindo a um direito supranacional; segundo porque notamos uma nítida hierarquia de regras deixando superiores as que tratarem de uma integração. O artigo 24 aprova tratados que deleguem competências e jurisdição a organizações supraestatais, em condições de reciprocidade e igualdade, respeitando os direitos humanos. Ao lado da Constituição paraguaia esta é a mais avançada no Mercosul.

\subsection{A Constituição Paraguaia}


Promulgada em 20 de junho de 1992 esta é a única Constituição do Mercosul que admite literalmente uma ordem jurídica supranacional, sendo também a que dedica o maior número de artigos às relações internacionais, portanto citaremos apenas os de maior relevância:

\section{Artículo 137.}

De la supremacia de la Constitucion.

La ley suprema de la República es la Constitución. Esta, los tratados, convenios y acuerdos internacionales aprobados e ratificados, las leyes dictadas por el Congreso y otras disposiciones jurídicas de inferior jerarquía, sancionadas en consecuencia, integran el derecho positivo nacional en el orden de prelación enunciado.

Artículo 154.

Del orden jurídico supranacional.

La republica del Paraguay, en condiciones de igualdad con otros Estados, admite un orden jurídico supranacional que garantice la vigencia de los derechos humanos, de la paz, de la justicia, de la cooperación y del desarrolo, en lo político, económico, social y cultural.

A posição hierárquica dos tratados nesta Constituição fica entre esta e as leis ordinárias. Não há diferença positivada também entre os acordos firmados com os países latino-americanos e demais países.

\subsection{A Constituição Uruguaia}

Assim como a Constituição brasileira, a paraguaia não tem nenhuma menção à supranacionalidade, notamos exatamente o contrário de acordo com o disposto no seguinte artigo:

Seccion I (...)

Capítulo II

Artículo 4. La soberanía en toda su plenitud existe radicalmente en la Nación, a la que compete el 
derecho exclusivo de estabelecer su leyes, del modo que más adelante se expresará

Vemos que esta impõe exclusividade nacional para estabelecer suas leis vigentes. Em outro dispositivo define-se a integração latina como algo que deve ser procurado, bem longe isto de um Mercado Comum, por exemplo.

\subsection{A Constituição Brasileira}

Ao contrário da maioria das Constituições mundiais, a brasileira constantemente deixa de lado a regulamentação entre o direito interno e o direito internacional. É este ponto que vários renomados autores consideram a grande omissão tratando-se de questões internacionais. O artigo 4, no seu parágrafo único deixa certo que existe a permissão constitucional para uma negociação visando uma integração latino-americana; contudo o texto constitucional não esclarece de maneira expressa se esta pode se dar através de um organismo supranacional, ou se deve-se respeitar o conceito clássico de soberania. Pedro Dallari diz que "não se cogita constitucionalmente da transferência de soberania para organizações supranacionais", logo não podemos falar em primazia do direito comunitário. Queremos sucesso no Mercosul? Então necessitamos urgentemente de uma revisão constitucional, e para isto basta vontade política. Para esta análise deixo em anexo uma tabela com a opinião das elites dos nossos vizinhos e nossa ao fim deste trabalho.

\section{A IMPORTÂNCIA DA SUPRANACIONALIDADE PARA $O$ MERCOSUL}

A supranacionalidade não é, em geral, muito benquista pelos Estados que visam a um processo de integração pelo fato de culminar em cessão de parcela da soberania. E no MERCOSUL, não foi diferente: Brasil e Uruguai impuseram em suas Constituições certas barreiras à instituição da supranacionalidade. 
A Constituição da República Federativa do Brasil de 1988 não acolheu qualquer expressa previsão quanto à supranacionalidade das normas do Mercado Comum do Sul ${ }^{7}$, o que se pode considerar como uma grande omissão em se tratando de questão internacional. Além dessa omissão, há ainda certos entraves à sua instituição. À guisa de exemplos, citase o art. 1o, I; art. 4o, I; art. 102, III,b; art. 49, I; dentre outros. A Constituição da República Oriental do Uruguai, em seu art. 6o, refere-se apenas a uma integração social e econômica dos Estados Latino-Americanos relativos à defesa comum de seus produtos e matérias-primas ou para uma efetiva complementação de seus serviços públicos sem, destarte, fazer referência a um mercado comum.

Já nas Constituições da Argentina e Paraguai, é possível perceber-se referências à supranacionalidade. No art. 145 da Constituição da República do Paraguai de 1992, admite-se uma ordem jurídica supranacional, de forma literal, desde que haja igualdade com outros Estados. A Constituição da Nação Argentina, além da igualdade, abarca ainda como requisito a reciprocidade.

Conforme expõe Elizabeth Accioly Pinto de Almeida, nenhum bloco econômico que tenha a ambição de converter-se em um mercado comum que disponha de livre circulação de pessoas, mercadorias, capitais e serviços pode prosperar sem que seus membros tenham um poder supranacional que dite as regras a serem seguidas por todos eles; que exija o cumprimento das mesmas e que dê aos cidadãos que a ele pertencem a garantia de seus direitos e deveres neste novo espaço econômico, político e social. ${ }^{8}$

Desta forma, se realmente se deseja um efetiva integração entre os Estados-partes do MERCOSUL e se espera que este prospere e adquira ainda mais credibilidade, solidez e confiabilidade, em especial, no âmbito externo, a adoção da supranacionalidade é o caminho a ser seguido. Afinal, um bloco com intenção de ser o segundo mercado comum do mundo ${ }^{9}$ deve estruturar-se de um forma altamente eficaz, algo que a supranacionalidade ajudaria a engendrar, isto porque, além das características próprias ou essenciais já enumeradas anteriormente, ela introduziria uma uniformidade de interpretação e aplicação do Direito nos Estados-partes, bem como responsabilizaria estes diretamente pela violação de alguma norma editada pelo órgão supranacional.

Harmonização ou uniformização? Essa foi a discussão levantada pelo professor de Direito Internacional Privado da PUC de Minas Gerais, 
Eduardo Grebler, durante a apresentação do painel sobre Harmonização Legislativa no $2^{\circ}$ Encontro de Cortes Supremas do Mercosul.

Para Grebler, na harmonização legislativa busca-se compatibilizar normas jurídicas conflitantes entre si, de modo a ajustarem-se a um paradigma consensualmente estabelecido pelos Estados. Já a uniformização legislativa, segundo ele, pretende estabelecer normas jurídicas efetivamente homogêneas, que reflitam identidade normativa nos territórios de todos os Estados-partes envolvidos. "O modo de fazê-lo é a celebração de tratados normativos, mediante os quais os Estados-partes assumem, uns perante os outros, a obrigação de internalizá-los em seus respectivos territórios adotando um só texto", dispõe.

O professor acredita que esse texto uniforme produziria efeito semelhante ao que teria uma eventual norma supranacional porque vigente em todos os espaços territoriais nacionais. Ele citou que, em âmbito mundial, a uniformização tem sido o objetivo de diferentes instituições como a Conferência de Haia, as Convenções de Genebra sobre Notas Promissórias e Letras de Câmbio e sobre Cheques.

Ele ressaltou, ainda, que o próprio Mercosul tem realizado a uniformização legislativa apontando como exemplo o Protocolo de Las Leñas sobre Cooperação e Assistência Jurisdicional de 1992, o Protocolo de Outro Preto sobre Medidas Cautelares de 1994, entre outros. Disse, porém, que inúmeros temas estão a exigir abordagem homogênea pelos Estadospartes do Mercosul como a propriedade intelectual e a repressão à pirataria e contrafação.

Eduardo Grebler também se referiu ao papel que os poderes judiciários podem ou devem exercer em prol da integração. Ele ressaltou que as várias manifestações de apoio ao processo de integração latino-americano, do qual o Mercosul é o mais visível exemplo, não têm sido coincidentes com pronunciamentos da Justiça brasileira.

Grebler disse que a posição do Supremo Tribunal Federal brasileiro tem sido invariável, no sentido de que a lei interna posterior prevalece sobre o tratado que lhe for anterior. "No entender do STF, deve-se assegurar a última palavra ao Congresso Nacional, ainda que importe afronta a um compromisso internacional do país, o que constituiria apenas um fato político, e não jurídico", assinalou o jurista.

O professor da PUC/MG sustentou que, se por um lado o Supremo deve observar fielmente os ditames da Constituição da República, 
por outro, "é de se esperar que a Corte Suprema, no exercício de sua específica atribuição de intérprete e de aplicadora da Constituição, o faça de modo consentâneo com o princípio segundo o qual o fundamento da organização política brasileira se assenta na formação da comunidade latinoamericana de nações, da qual o Mercosul é a expressão", finalizou.

Atualmente há uma convergência relativa a respeito do modelo de desenvolvimento nacional entre os maiores parceiros do Mercosul, que não pode ser dificultada por eventuais retrocessos políticos ${ }^{16}$.

Para Clodoaldo Bueno “ o avanço e a consolidação do Mercosul depende muito ainda daqueles que ocupam transitoriamente o poder executivo dos países desenvolvidos" 17.

\section{APONTAMENTOS SOBRE O II ENCONTRO DE CORTES SUPREMAS DOS ESTADOS PARTES E ASSOCIADOS DO MERCOSUL}

No mês de novembro de 2004, ocorreu o Segundo Encontro de Cortes Supremas dos Estados Partes e Associados do Mercosul na cidade de Brasília - Distrito Federal , Brasil.

Pela importância que representou referido Encontro, que contou com a participação de juristas de vários países e pelos temas neles enfrentados, entendeu-se importante consigna-lo na presente monografia ${ }^{18}$.

Para facilitar o encontro de tamanha importância foram criados quatro grupos de trabalhos com o propósito do estudo dos seguintes temas : Assimetrias Constitucionais, Cooperação Judiciária, Harmonização Legislativa em Direito Material e Processual, Solução de Controvérsias.

O trabalho foi coordenado pela Senhora Ministra Ellen Gracie (Ministra do Supremo Tribunal Federal Brasileiro), quem em breve relatório consolidou o resultado e as sugestões dos grupos de trabalho, conforme se vê abaixo :

\footnotetext{
${ }^{16}$ BUENO, Clodoaldo. O Brasil no Mercosul: O olhar dos historiadores. Unesp Franca. Departamento de História, pág. 24.

${ }^{17}$ Ibidem.

18 Toda a degravação do evento encontra-se Disponível no endereço: www.stf.gov.br/encontro2/imagens/pdf/degravacao_mercosul.pdf. Acesso em 30.03.2008.
} 
Grupo $\mathrm{n}^{\mathrm{o}}$ 01, que tratou das Assimetrias Constitucionais, chegou às seguintes conclusões:

$\left.1^{\circ}\right)$ As Constituições da Argentina e do Paraguai reconhecem, expressamente, a possibilidade de convalidação de instituições supranacionais, bem como possuem norma específica sobre conflito entre a lei interna e os tratados, o que não é previsto nas Constituições brasileira e uruguaia;

$2^{\circ}$ ) Seria conveniente que, sob a perspectiva da segurança jurídica, os Estados brasileiro e uruguaio promovessem reformas constitucionais aptas a afastar apontada omissão;

$3^{\circ}$ ) Não se verificam, ademais, fatores impeditivos para que as Cortes Supremas do Brasil e do Uruguai caminhem no sentido de viabilizar, juridicamente, a vontade política conducente ao processo de integração;

$4^{\circ}$ ) Além dos instrumentos jurídicos permissivos de interpretações construtivas, em particular, a Convenção de Viena sobre Direito dos Tratados, de 23 de maio de 1969, os Poderes Judiciários devem buscar soluções internas que previnam a possibilidade de antinomia na interpretação e efetiva aplicação das normativas Mercosul;

$5^{\circ}$ ) Sem prejuízo das atribuições constitucionais de cada Poder constituído, é desejável que se estabeleça forma de diálogo interinstitucional com vista a preservar os esforços resultantes das negociações voltadas ao aprofundamento e à consolidação da integração regional em prol do desenvolvimento e do bem-estar de nossos povos.

As conclusões do Grupo $n^{\circ}$ 02, Cooperação Judiciária forma as seguintes:

$1^{\circ}$ ) Sem cooperação internacional, não exercício pleno do Poder jurisdicional nem efetividade das decisões judiciais;

$2^{\circ}$ ) Anotou, também, a existência de instrumentos normativos, no âmbito do Mercosul, em execução assídua pelos órgãos judiciários dos Estados-Partes;

$3^{\circ}$ ) Recomendou a atenção para instrumentos regionais sobre os mesmos temas, a exemplo das Convenções interamericanas de Direito Internacional Privado;

$4^{\circ}$ ) Demonstrou preocupação com jurisprudência que aplique, desmedidamente, a exceção de ordem pública, como limitação à cooperação judiciária internacional; 
$\left.5^{\circ}\right)$ Reconheceu ser desejável que o exame da admissibilidade dos pedidos de cooperação judiciária, especialmente no âmbito do Mercosul, não seja feito apenas de forma concentrada, mas também diretamente pelo juízo de primeiro grau competente para a execução da medida solicitada;

$\left.6^{\circ}\right)$ Parte do grupo concordou não haver obstáculos constitucionais à elaboração de tratados internacionais ou leis internas que autorizem a homologação de sentenças estrangeiras para efeitos penais, como confisco e perdimento de bens ou aplicação de penas restritivas de liberdade.

O Grupo $n^{\circ}$ 03, que cuidou da Harmonização Legislativa em Direito Material ou Processual alcançou as seguintes conclusões:

$1^{\circ}$ ) Salientou a relevância da existência de textos normativos coerentes com as finalidades do Mercosul, em matéria de Direito do Consumidor, da concorrência, da propriedade intelectual, da proteção de investimentos estrangeiros e de responsabilidade civil, contratual e extracontratutal, dentre outros;

$2^{\circ}$ ) Apontou, igualmente, a necessidade de aperfeiçoamento de normas processuais aptas a assegurar a efetividade da prestação jurisdicional nos contenciosos gerados em torno do comércio de bens e serviços do Mercosul;

$3^{\circ}$ ) Registrou a conveniência da criação de mecanismos que conduzam a uniformização dos critérios de interpretação das normas oriundas do processo de integração pelos diferentes Poderes Judiciários dos EstadosPartes e associados;

$4^{\circ}$ ) Recomendou que a Secretaria do Mercosul se incumba de propor os temas que devam ser objeto de esforço, de harmonização e/ou uniformização legislativa a partir do exame de situações concretas e das necessidades verificadas;

$\left.5^{\circ}\right)$ Propôs encorajarem-se os Poderes Judiciários nacionais, no sentido de atender aos compromissos dos seus respectivos estados, voltados à integração regional.

Finalmente, as conclusões do Grupo n ${ }^{\circ}$ 04, que cuidou da Solução de Controvérsias, forma as seguintes:

$\left.1^{\circ}\right)$ Concluiu-se que o Sistema de Solução de Controvérsias do Mercosul, mediante o Protocolo de Olivos, avançou, mas ainda demanda maior aperfeiçoamento; 
$2^{\circ}$ ) Ponderou-se que as opções do sistema de controvérsias do Mercosul e a sua prática, com nove laudos, com interpretações contraditórias sobre temas mais processuais do que materiais, levando à conclusão que eles não criaram uma interpretação comum sequer sobre a primazia da normativa Mercosul e sua relação com o Tratado Macro de ALADE;

$3^{\circ}$ ) Observou-se a necessidade de se desenvolver forma eficiente de garantir o acesso dos particulares ao sistema de controvérsias do Mercosul, de modo a não depender do exame unilateral do seu estado de domicílio.

$\left.4^{\circ}\right)$ Sugeriu-se, concretamente, interpretar o Protocolo de Olivos no sentido de que qualquer Tribunal nacional poderá enviar um pedido de opinião consultiva ao Tribunal Permanente de Revisão do Mercosul, desde que passe por juízo de admissibilidade da Corte Suprema do Estado-Parte respectivo;

$5^{\circ}$ ) Uma sugestão seria que os particulares, uma vez que entrassem com ações, frente ao juiz nacional, estes juízes e Tribunais Regionais tivessem a possibilidade de enviar para a sua Corte Superior, ou ainda, para um órgão a ser criado, que reúna as Cortes Supremas, um pedido de opinião consultiva para o Tribunal Permanente do Mercosul sobre este problema do particular que, depois, pudesse ser usada pelo Poder Judiciário.

As opiniões consultivas são um germe de supranacionalidade e uma chance para a interpretação uniforme da normativa do Mercosul.

Essas são, as conclusões dos quatro grupos de trabalho que demonstram a tendência do direito para o Mercosul.

\section{CONSIDERAÇÕES FINAIS}

Após levantamento bibliográfico e estudo acerca do tema, qual seja a legislação aplicável no Mercosul e a necessidade de uma hormanização legislativa, pode-se concluir que é extremamente importante e constitui uma realidade para os Países que integram o cône sul das américas.

No âmbito jurídico se identificou as maiores dificuldades para harmonização do processo legislativo da área de livre comércio do Mercosul. Primeiro, acreditava-se que a origem e afinidade entre os signatários seriam elementos que facilitariam a harmolização legislativa, porém tal fato não ocorreu, justamente pelas características, experiências sociais e a 
cultura de cada um, demonstraram enorme dificuldade para alcançar objetivo, ou seja, Direito comum aos intergrantes.

Várias reuniões foram realizadas entre os Países membros do bloco Mercosul, uma delas aconteceu no Brasil, Brasília-DF, com participação de países associados, representantes europeus, estudiosos, empesários, em suma, todos os interessados e envolvidos, justamente com objetivo e fomentar leis comuns, conferir maior segurança jurídica e harmonização legislativa ao bloco.

Pensou-se em um Direito próprio, material e processual, com força política de inserção na ordem interna dos países-membros, afastando o direito estrangeiro ou inernacional, entretanto, não se consumou até então.

Sugeriu-se em um Direito no Mercosul fundamental para proteção dos direitos econômicos e até chegaram a cogitar a criação de normas mínimas de garantia de direitos trabalhistas e direitos humanos, bem como debateram sobre o papel do juiz na solução de conflitos advindos do Mercosul. Porém, não chegaram harmonizar a legislação ao ponto de atender os interesses dos associados e interessados no bloco econômico-administrativo.

Conclui-se ainda, que não só as leis de cada signatário, as experiências sociais e a cultura de cada País, mas as diferenças de estrutura orgânica entre os mercados comuns, europeu e mercosul, são marcas que dificulta uma harmonização à legislação para bolo sulamericano.

Porém, há que se registrar pela pesquisa que houve significativo avanço as reuniões e os debates com o propósito de fomentar e alcançar a harmonização de uma legislação para o Mercosul, assinando um Protocolo Adicional do Tratado de Assunção sobre a Estrutura Institucional do Mercosul denomiando "Protocolo de Ouro Preto", visando manter um mínimo de estrutura administrativa e jurídica, permitindo o livre comércio entre os associados, até que se alcance a pretendida uniformização da legislação.

A Estrutura Institucional do Mercosul, criada por meio do referido Protocolo Adicional do Tratado de Assunção,embora o tenha personificado, manteve e se acha composta dos seguintes órgãos durante o período de transição: o Conselho do Mercado Comum, o Grupo Mercado Comum e a Comissão Parlamentar Conjunta e criou a Comissão de Comércio do Mercosul, o Foro Consultivo Econômico-Social e a Secretaria Administrativa do Mercosul.

Nenhum dos seis órgãos tem caráter supranacional. 
A própria Comissão Parlamentar Conjunta é um órgão representativo dos Parlamentos nacionais no seio do Mercosul, deixando claro por meio do artigo 23 do Protocolo, que os integrantes da Comissão são 'parlamentares representantes dos Estados - Partes', e não representantes de seus povos.

Assim, em virtude do caráter intergovernamental dos órgãos do Mercosul dotados de capacidade decisória, a harmonização das legislações fica restrita a decisões do Conselho do Mercado Comum e a convenções entre os Estados-Partes.

Portanto, via conseguinte há que se registrar que as decisões do Conselho do Mercosul não produzem efeitos diretos sobre os ordenamentos jurídicos dos Estados-Partes, apenas vincula-os no sentido de introduzirem as normas de harmonização em seus respectivos ordenamentos jurídicos, através da hierarquia de lei, se esta for reguladora da matéria, ou, ainda, se competir ao Parlamento nacional a delimitação da matéria.

Assim, com base na necessidade de fortalecimento do processo de integração, visando reduzir as incompatibilidades por meio de um conjunto de regras harmônicas, entre os estados - partes, tendo como fundamento o Direito da Integração com aplicação interna das normas em cada País participante, com capacidade decisória, dentro de seus territórios, não há, como acima registrado, um órgão de caráter supranacional, mas há compromisso dos signatários de harmonizar a legislação nos moldes do modelo supranacional da União Européia.

Relamente, como registrado, tem-se condição para se alcançar o Mercado Comum, a unificação de certos regramentos jurídicos, de forma a possibilitar iguais condições de competição entre os países integrados, observando-se a distinção clara entre coordenação, harmonização e aproximação para fins manter a integração e funcionamento do Mercado Comum, apesar do sistema de intergovernamentabilidade adotado seja uma barreira para se alcançar a integração pretendida.

\section{REFERÊNCIAS BIBLIOGRÁFICAS}

ABREU, Sérgio, FLORÊNCIO, Lima. O perfil multilateral do comércio brasileiro e a construção do Mercosul. Ministério das Relações Exteriores, São Paulo, 2003. Disponível em : 
http://www.mre.gov.br/unir/webunir/BILA/07/1 artigos/artigo4.htm

ALABY, Michel Abdo. O Mercosul e a estratégia empresarial - o caminho s integração.

ALMEIDA, Paulo Roberto de. Dez anos de Mercosul: uma visão brasileira. Scientia Iuris: Revista do Curso de Mestrado em Direito Negocial da UEL, Universidade Estadual de Londrina - vol. 1, N. ${ }^{\circ}$ 1, (Jul/Dez) - Londrina: Ed. Da UEL, 1997.

- Mercosul no contexto regional e internacional. São Paulo: Aduaneiras, 1993.

ARAÚJO, Clarice. Aspectos tributários para a integração dos países signatários do Mercosul. Direito da integração/ Coordenadora Rachel Sztajn - São Paulo: Cultural Paulista: Unicid, 2001.

BÖHLKE, Marcelo. Integração regional e autonomia do seu ordenamento jurídico. Curitiba: Juruá, 2002.

BRASIL. Bacen - BANCO CENTRAL DO BRASIL - Diretoria de Assuntos Internacionais - Direx - Departamento da Dívida Externa e de Relações Internacionais - Derin Consultoria para Assuntos de Integração - Coint, em seu Boletim Mercosul: Assuntos Financeiros - Informações Selecionadas N. 31 - Julho/Dezembro - 2002. Disponível em: http://www,bcb.gov.br/,Pag.asp?Perfil=1\&cod=325\&codP231.

COELHO, Fábio Ulhoa. Curso de direito comercial. Vol. 1. 7. Ed. São Paulo: Saraiva, 2003.

CORRÊA, Antonio. Mercosul: soluções de conflitos pelos juízes brasileiros. Porto Alegre: Sérgio Antonio Fabris Editor, 1997.

FARIA, Guiomar T. Estella. As sociedades comerciais e a formação de blocos econômicos de nações. In: Mercosul: seus efeitos jurídicos, econômicos e políticos nos Estados - Membros. Org. Maristela Basso - 2, ed. - Porto alegre: Livraria do Advogado, 1997.

FARIA, Werter R. A integração Econômica e o Direito Comercial. Ministério das Relações Exteriores, SãoPaulo, 2003. Disponívelem: http://www,mre.gob.br.unir/webunir/BILA/11/artigos/5artigo.htm

Métodos de Harmonização aplicáveis no Mercosul e incorporação das normas correspondentes nas ordens jurídicas internas. In: Mercosul: seus efeitos jurídicos, econômicos e políticos nos Estados - Membros. Org. Maristela Basso. - 2. Ed. Porto Alegra: Livraria do Advogado, 1997 
JUCÁ, Francisco Pedro. Institucionalização do Mercosul: integração e fortalecimento. Revista da Associação dos Juízes do Rio Grande do Sul. Rio Grande do Sul, Novembro/1998.

LIMA, Sérgio Mourão Corrêa. Tratados internacionais no Brasil e integração. São Paulo: LTr, 1998.

LIPOVETZKY, Jaime César, LIPOVETZKY, Daniel Andrés. Mercosul, estratégia para a integração. São Paulo: LTr, 1994.

MACHADO, João Bosco M. Harnonização comercial, convergência cambial e política industrial no Mercosul. Ministério das Relações Exteriores, são Paulo, 2003. Disponível em: http://www,mre.gov.br/ubi/webunir/BILA/11?artigos/2artigo.htm.

MARTOS, Frederico Thales de Araújo. Rentabilidade e Planejamento: As diretrizes jurídicas da empresa socialmente consciente. Franca: Editora Lemos \& Cruz, 2015, 160p.

MARTOS, Frederico Thales de Araujo, MARTOS José Antonio de Faria, Las interceptaciones telefónicas en los países del Mercosur: doctrina y Jurisprudencia en el proceso civil .Franca: Editora Lemos \& Cruz, 2015, 256p.

MARTOS, Frederico Thales de Araújo. Direito Empresarial Moderno: A função social da empresa contemporânea. Franca: Editora Lemos e Cruz, 2015, 209p.

MERCOSUL. Cronologia do Mercosul. Disponível em: http://www.mercosul.gov.br/textos/default.asp?Key=47

Decisões do Conselho Mercado Comum. Disponível em: http://www.mercosul.gov.br

Protocolo de Brasília. Disponível em: http://antaq.gov.br/integracao/mercosul/protocolo_bsb.htm

Protocolo de Ouro Preto. Disponível em: http://www.mercosul.gov.br/textos.default.asp?Key=17

Tratado de Assunção. Disponível em: http://www.mercosul.gov.br/textos/default.asp?Key=45

PABST, Haroldo. Unificação do direito comercial no Mercosul. Ministério das Relações Exteriores, São Paulo, 2003. Disponível em: http://www.mre.gov.br/unir/webunir/BILA/07/1artigos.

PORTUDAL, Heloísa de Almeida. Atividade empresarial e liberdade de estabelecimento no Mercosul. Curitiba: Juruá, 2001.

RANGEL, Vicente Marotta. Solução pacífica de controvérsias no Mercosul: estudo preliminar. Revista as Associação dos Juízes do Rio Grande do Sul, novembro/1119. 
REIS, Márcio Monteiro. Mercosul, União Européia e constituição: a integração dos estados e os ornamentos jurídicos nacionais. Rio de Janeiro: Renovar, 2001.

REYES, Jorge Enrique Fernández. Evaluación de los mecanismos de solución de controvérsias en el Mercosur. Revista de Direito Internacional e Mercosul, Buenos Aires, n. 4, p. 159-169, ago. 2000. SANTOS, Ricardo Soares Stersi dos. Mercosul e arbitragem internacional comercial: aspectos gerais e algumas possibilidades. Belo Horizonte: Del Rey, 1997.

SILVA, Roberto Luiz. Direito econômico internacional e direito comunitário. Belo Horizonte: Del Rey, 1995.

SOARESm Guido F. S. As instituições do Mercosul e as soluções de litígios no seu âmbito - sugestões lege ferenda. Mercosul: das negociações a implantação/organizadores Luiz Olavo Baptista, Araminta de Azevedo Mercadante e Paulo Borba Caslla. São Paulo: LTr, 1994.

UNIÃO EUROPËIA. Disponível em: 〈http//www,europa.eu.int〉. . Tratado de Maastricht. Disponível em: http://europa.int. 